\title{
Thermococcus hydrothermalis sp. nov., a New Hyperthermophilic Archaeon Isolated from a Deep-Sea Hydrothermal Vent
}

\author{
ANNE GODFROY, ${ }^{1 *}$ FRANÇOISE LESONGEUR, ${ }^{1}$ GÉRARD RAGUÉNÈS, ${ }^{1}$ JOËL QUÉRELLOU, \\ ELISABETH ANTOINE, 'JEAN-ROCH MEUNIER, ${ }^{1,2} \dagger$ JEAN GUEZENNEC, ${ }^{1}$ \\ AND GEORGES BARBIER ${ }^{1}$

\begin{abstract}
Laboratoire de Biotechnologie, Département Environnement Profond, IFREMER, Centre de Brest, 29280 Plouzané, ${ }^{1}$ and Unité des Entérobactéries, Institut Pasteur, 75724 Paris cedex $15,^{2}$ France
\end{abstract}

\begin{abstract}
An extremely thermophilic archaeon, strain $\mathrm{AL}_{662}{ }^{\mathrm{T}}$, was isolated from a deep-sea hydrothermal vent located on the East Pacific Rise at a latitude of $21^{\circ} \mathrm{N}$. This strain is a strictly anaerobic coccus, and its cells range from 0.8 to $2 \mu \mathrm{m}$ in diameter. The optimum temperature, $\mathrm{pH}$, and Sea Salt concentration for growth are $85^{\circ} \mathrm{C}, 6$, and 20 to $\mathbf{4 0}$ g/liter, respectively. Strain $\mathrm{AL662}^{\mathrm{T}}$ grows preferentially on proteolysis products, on a mixture of 20 amino acids, and on maltose in the presence of elemental sulfur. The membrane lipids consist of di- and tetraether glycerol lipids. The DNA G+C content is $58 \mathrm{~mol} \%$. Sequencing of the $16 \mathrm{~S}$ rRNA gene showed that strain AL662 ${ }^{\mathrm{T}}$ belongs to the genus Thermococcus. On the basis of hybridization results, we propose that this strain should be placed in a new species, Thermococcus hydrothermalis.
\end{abstract}

Since the discovery of hyperthermophilic archaea, strains belonging to the order Thermococcales have been isolated from both terrestrial and marine hot environments and described. Species belonging to the genus Thermococcus have been isolated from various deep-sea and shallow marine hydrothermal areas and described. All of the strains have quite similar physiological characteristics and can be divided into the following two groups on the basis of their $\mathrm{G}+\mathrm{C}$ contents: (i) a group of strains with high $\mathrm{G}+\mathrm{C}$ contents $(50$ to $58 \mathrm{~mol} \%$ ), including strains belonging to two species from shallow marine environments, Thermococcus celer (34) and Thermococcus stetteri (20), and three species from deep-sea environments, Thermococcus profundus (14), "Thermococcus peptonophilus" (8), and Thermococcus fumicolans (7); and (ii) a group of strains with low $\mathrm{G}+\mathrm{C}$ contents ( 38 to $47 \mathrm{~mol} \%$ ), including strains belonging to two species from deep-sea environments, "Thermococcus chitonophagus" (11) and "Thermococcus alcaliphilus" (13), and an organism from a shallow marine environment, "Thermococcus litoralis" (22). All of these species are able to use proteinaceous carbon substrates in the absence or presence of sulfur. Some of these strains are able to grow in the absence of elemental sulfur, but sulfur greatly enhances growth. In this paper, we describe a new hyperthermophilic heterotrophic archaeal species that was isolated from a deep-sea hydrothermal vent on the East Pacific Rise at a latitude of $21^{\circ} \mathrm{N}$. This organism was selected on the basis of the results of a preliminary screening for alcohol dehydrogenase (ADH) activity in 71 hyperthermophilic heterotrophic strains that were isolated at 80 and $95^{\circ} \mathrm{C}$ from various deep-sea hydrothermal vent areas (15).

\section{MATERIALS AND METHODS}

Reference strains. Thermococcus celer DSM $2476^{\mathrm{T}}$ " "Thermococcus litoralis" DSM $5474^{\mathrm{T}}$, Thermococcus stetteri DSM $5262^{\mathrm{T}}$, Sulfolobus acidocaldarius DSM $639^{\mathrm{T}}$, and Thermotoga maritima DSM $3109^{\mathrm{T}}$ were obtained from the Deutsche Sammlung von Mikroorganismen, Braunschweig-Stöckeim, Germany. Other strains were directly obtained from researchers. Thermococcus profundus

* Corresponding author. Mailing address: Laboratoire de Caractérisation des Microorganismes Marins, DRV/VP, IFREMER, Centre de Brest, BP70, 29280 Plouzané, France.

$\dagger$ Present address: L'OREAL, Recherche Avancée, DCSP, Phototoxicité, 93600 Aulnay-sous-Bois, France.
DT5432 ${ }^{\mathrm{T}}$ was provided by Tetsuo Kobayashi (RIKEN, Wako, Japan). Thermococcus fumicolans CIP104680 ${ }^{\mathrm{T}}$ was isolated in our laboratory.

Growth conditions. 2216-S medium (2) contains (per liter) $2 \mathrm{~g}$ of peptone, $0.5 \mathrm{~g}$ of yeast extract, $30 \mathrm{~g}$ of Sea Salt (Sigma Chemical Co., St. Louis, Mo.), $6.05 \mathrm{~g}$ of PIPES [piperazine- $N, N^{\prime}$-bis(ethanesulfonic acid)] buffer (Sigma), $10 \mathrm{~g}$ of sulfur, and $1 \mathrm{mg}$ of resazurin. BHI-S medium contains (per liter) $9 \mathrm{~g}$ of brain heart infusion, $23 \mathrm{~g}$ of $\mathrm{NaCl}$ (instead of Sea Salt, to prevent formation of a mineral precipitate), $6.05 \mathrm{~g}$ of PIPES buffer, $10 \mathrm{~g}$ of sulfur, and $0.5 \mathrm{mg}$ of resazurin. 20AA-S medium contains (per liter) $30 \mathrm{~g}$ of Sea Salt, $6.05 \mathrm{~g}$ of PIPES buffer, $10 \mathrm{~g}$ of sulfur, $1 \mathrm{mg}$ of resazurin, $10 \mathrm{ml}$ of a mineral solution (1), and 10 $\mathrm{ml}$ of a vitamin solution (1) and each of the 20 classical amino acids at a concentration of $0.2 \mathrm{mM}$. A stock solution containing each of the amino acids at a concentration of $2 \mathrm{mM}$ was sterilized separately by filtration (pore size, 0.22 $\mu \mathrm{m}$; Nalgene filterware). Unless indicated otherwise, the $\mathrm{pH}$ was adjusted to 5.5 with $5 \mathrm{~N} \mathrm{NaOH}$. In each case, the medium was sterilized by steaming it at $100^{\circ} \mathrm{C}$ for 30 min on 2 successive days, transferred into an anaerobic chamber containing $\mathrm{N}_{2}, \mathrm{H}_{2}$, and $\mathrm{CO}_{2}(90: 5: 5)$, reduced by adding sodium sulfide to a final concentration of $0.5 \mathrm{~g} /$ liter, and then distributed into Hungate tubes or into $50-\mathrm{ml}$ serum vials with butyl rubber stoppers. Unless indicated otherwise, cultures were grown on 2216-S medium at $\mathrm{pH} 5.5$ and incubated at atmospheric pressure under the anaerobic chamber gas mixture at $80^{\circ} \mathrm{C}$

Enrichment cultures and purification. After samples (rock suspensions) were collected, they were stored at room temperature in serum vials filled with sterile seawater under anaerobic conditions $\left(\mathrm{N}_{2}\right.$ headspace gas and $0.5 \mathrm{~g}$ of sodium sulfide per liter). Enrichment cultures were grown on 2216-S medium that was incubated at $80^{\circ} \mathrm{C}$ for 2 or 3 days. Cultures were purified by streaking samples onto 2216-S medium that was solidified with Gelrite (Scott Laboratories, Long Island, N.Y.) and incubated in anaerobic jars at $80^{\circ} \mathrm{C}$ (6). Purified isolates were stored at $4^{\circ} \mathrm{C}$ and could be used as inocula for at least 1 year. For long-term storage, pure cultures were stored anaerobically at $-70^{\circ} \mathrm{C}$ in the presence of $5 \%$ (wt/vol) dimethyl sulfoxide (Sigma) as a cryoprotectant.

Determination of cell number. The numbers of cells were determined by direct cell counting by using a Thoma chamber (depth, $0.02 \mathrm{~mm}$ ). When cells were grown on medium containing high particle concentrations (e.g., on culture medium supplemented with starch or on medium at temperatures above $100^{\circ} \mathrm{C}$ ), the numbers of cells were determined by epifluorescence $(10)$. Samples were diluted in sterile water containing Sea Salt $(30 \mathrm{~g} /$ liter $)$, formalin $(2.5 \%)$, and acridine orange $(0.01 \%)$, filtered with black polycarbonate membrane filters (pore size, $0.2 \mu \mathrm{m}$; Nuclepore), and observed with an Olympus model BH-2 microscope.

Determination of growth parameters. To determine the optimum temperature, cells were grown in Hungate tubes containing $6 \mathrm{ml}$ of 2216-S medium. The headspace gas was $\mathrm{N}_{2}-\mathrm{CO}_{2}-\mathrm{H}_{2}(90: 5: 5)$ at a pressure of $100 \mathrm{kPa}$ for temperatures under $100^{\circ} \mathrm{C}$ and at a pressure of $200 \mathrm{kPa}$ for temperatures of $100^{\circ} \mathrm{C}$ or more. Temperatures were maintained with aluminum heating blocks (Bioblock, Illkirch, France) and were monitored with temperature probes placed in control tubes. To determine growth rates at different $\mathrm{pHs}, 2216-\mathrm{S}$ medium was modified by using the following buffers (Sigma), each at a concentration of $1 \mathrm{~g} /$ /iter: for $\mathrm{pH}$ $2.5,3.5$, and 4.5, no buffer; for $\mathrm{pH} 5.5$, MES (morpholineethanesulfonic acid) buffer; for pH 6.5, PIPES buffer; for pH 7.5, HEPES ( $N$-2-hydroxyethylpiperazine- $N^{\prime}-2$-ethanesulfonic acid) buffer; and for $\mathrm{pH} 8.5$ and 9.5, AMPSO [3-(1,1dimethyl-2-hydroxyethyl)amino)-2-hydroxypropanesulfonic acid] buffer. After sodium sulfide was added, the $\mathrm{pH}$ was adjusted with $1 \mathrm{M} \mathrm{HCl}$. To determine the salt requirement, 2216-S medium was prepared with different dilutions of Sea 
Salt. The effects of $\mathrm{pH}$ and salinity were determined at $80^{\circ} \mathrm{C}$. Three replicates were studicd simultaneously at each temperature, $\mathrm{pH}$, or salinity.

Determination of growth requirements. The ability of isolate AL662 $\mathrm{T}^{\mathrm{T}}$ to utilize various carbon sources was tested in media in which the yeast extract and peptone of $2216-\mathrm{S}$ medium were replaced by $0.4 \mathrm{~g}$ of ammonium chloride per liter, $10 \mathrm{ml}$ of a mineral solution (1) per liter, $10 \mathrm{ml}$ of a vitamin solution (1) per liter, and carbon sources. Tests were performed by using tubes containing no nitrogen and no carbon substrates as controls for growth on substrates carried over in the inoculum. Most of the carbon sources were tested at a concentration of $5 \mathrm{~g}$ /liter; the exceptions were starch, which was tested at a concentration of 10 $\mathrm{g} / \mathrm{liter}$, and ethanol, which was tested at a concentration of $5 \mathrm{ml} / \mathrm{liter}$. Growth on $\mathrm{BHI}-\mathrm{S}$ medium and growth on 20AA-S medium were also tested. In addition, autotrophic growth with $\mathrm{H}_{2}-\mathrm{CO}_{2}(80: 20)$ headspace gas as the sole carbon source was tested. To determine the ability of the isolate to grow in the absence of elemental sulfur, cells were cultured on 2216-S medium from which sulfur compounds had been omitted. In this experiment, the headspace gases were $\mathrm{N}_{2}$, $\mathrm{N}_{2}-\mathrm{CO}_{2}(80: 20)$, and $\mathrm{H}_{2}-\mathrm{CO}_{2}(80: 20)$ at a pressure of $100 \mathrm{kPa}$, and the medium was reduced by adding titanium nitrilotriacetate (21) at a concentration of 200 $\mu \mathrm{M}$. Growth on cystine ( $10 \mathrm{~g} / \mathrm{liter})$ and growth on polysulfide $(10 \mathrm{mM})(4)$ were also investigated.

Antibiotic susceptibility. Susceptibility to the antibiotics vancomycin, penicillin, kanamycin, streptomycin, rifampin, and chloramphenicol, each at a final concentration of $100 \mu \mathrm{g} / \mathrm{ml}$, was determined under the standard growth conditions. Thernotoga maritima was used as a control to establish the effectiveness of antibiotics at $80^{\circ} \mathrm{C}$.

Electron microscopy. For transmission electron microscopy, cells were harvested at the end of the log phase. The pellet was resuspended and fixed for $1 \mathrm{~h}$ at room temperature in $0.4 \mathrm{M}$ cacodylate buffer $(\mathrm{pH} 7.4)-5.5 \% \mathrm{NaCl}-8 \%$ glutaraldehyde $(2: 1: 1)$ and then postfixed for $1 \mathrm{~h}$ at $4^{\circ} \mathrm{C}$ in $0.4 \mathrm{M}$ cacodylate buffer $(\mathrm{pH} 7.4)-10 \% \mathrm{NaCl}-2 \% \mathrm{OsO}_{4}(1: 1: 2)$. After dehydration with increasing ethanol concentrations, cells were embedded in Spurr's resin, thin sectioned, contrasted with $1 \%$ (wt/vol) uranyl acetate and $1 \%$ (wt/vol) lead citrate (Bio-Rad S.A., Ivry, France), and examined with a model EM201 transmission microscope (Philips, Eindhoven, The Netherlands).

Lipid analysis. (i) Lipid extraction. Lipids were extracted from lyophilized cells $(50$ to $100 \mathrm{mg}$ ) by using a modified Bligh-Dyer method $(3,33)$. The extracted lipids were tractionated into neutral lipids, glycolipids, and polar lipids by silicic acid column chromatography by using chloroform, acetone, and methanol, respectively. The methanol fraction containing polar ether lipids was dried under a vacuum and stored under $\mathrm{N}_{2}$ until further analysis. The lipid-extracted residue was hydrolyzed in $1 \mathrm{~N} \mathrm{HCl}\left(5 \mathrm{~h}\right.$ at $\left.100^{\circ} \mathrm{C}\right)$. After cooling, the solution was transferred to a separatory funnel with washes of dichloromethane. Two phases were allowed to separate, and the organic phase containing the bound ether lipids was collected for further analysis.

(ii) Glycerol ether analysis. The polar phase of the Bligh-Dyer extraction preparation was subjected to strong acid hydrolysis, and the resulting core ether lipids were digested with $55 \% \mathrm{HI}$ for $18 \mathrm{~h}$ at $100^{\circ} \mathrm{C}$. The resulting alkyl iodides were extracted with hexane and successively washed with $\mathrm{Na}_{2} \mathrm{~S}_{2} \mathrm{O}_{3}$ and $\mathrm{Na}_{2} \mathrm{CO}_{3}$ solutions (12, 16, 23). After extraction with hexane, the iodide derivatives were analyzed by gas chromatography with an instrument equipped with an electron capture detector by using 1,2 di-o-hexadecyl-rac-glycerol as the internal standard. Authentic glycerol diethers and diglycerol tetraethers were purchased from Sigma or were isolated from $S$. acidocaldarius

Organic acid production. The isolate was grown on BHI-S medium and on $20 \mathrm{AA}-\mathrm{S}$ medium at $80^{\circ} \mathrm{C}$ for $15 \mathrm{~h}$. Organic acids were analyzed by gas chromatography and gas chromatography-mass spectrometry as ter-butyl dimethylsilyl derivatives (27).

DNA base composition. Cells were cultured in 4.5 liters of $2216-\mathrm{S}$ medium at $80^{\circ} \mathrm{C}$ and harvested at the end of the exponential phase of growth. After centrifugation, the cell pellet was suspended in $5 \mathrm{ml}$ of lysis buffer $(100 \mathrm{mM}$ Tris$\mathrm{HCl}, 100 \mathrm{mM} \mathrm{NaCl}, 0.50 \mathrm{mM}$ EDTA; $\mathrm{pH} \mathrm{8}$ ), $1 \%$ (wt/vol) Sarkosyl was added, and then $1 \%$ (wt/vol) sodium dodecyl sulfate and proteinase $\mathrm{K}$ (final concentration, $0.4 \mathrm{mg}$ /liter) were added for cell lysis. After $3 \mathrm{~h}$ of incubation at $40^{\circ} \mathrm{C}$, three phenol-chloroform-isoamyl alcohol $(24: 24: 1)$ extractions and one chloroform extraction were performed. The DNA was precipitated by adding 2 volumes of cthanol at $-20^{\circ} \mathrm{C}$. The DNA pellet was resuspended in TE buffer $(10 \mathrm{mM}$ Tris-HCl, $2 \mathrm{mM}$ EDTA; $\mathrm{pH} 7.4)$ and treated with RNase $(5 \mu \mathrm{g} /$ liter $)$ for $1 \mathrm{~h}$ at $60^{\circ} \mathrm{C}$. The DNA base composition was determined by the thermal denaturation method (19)

16S rRNA sequence analysis. The rrs gene was amplified by PCR (28) as described previously (5), except that archaeon-specific primers were used. The primer sequences were 5'-TCC GGT TGA TCC TGC CGG AC-3' (Escherichia coli $16 \mathrm{~S}$ rRNA gene positions 2 to 21) and 5'-CTT TCG GTC GCC CCT ACT-3' (Thermococcus celer 23S rRNA gene positions 257 to 234). As described in the SureClone ligation kit (Pharmacia Biotech, Orsay, France) protocol, the purified PCR product was prepared for ligation by using the $3^{\prime}-5^{\prime}$ exonuclease activity of the Klenow tragment to remove single-base $3^{\prime}$ overhangs on the fragments. The PCR fragments were concomitantly phosphorylated with T4 polynucleotide kinase. After phenol-chloroform-isoamyl alcohol (24:24:1) extraction and MicroSpin column (Pharmacia) purification, the PCR product was ligated to a SmaIdigested and calf intestine alkaline phosphatase-dephosphorylated BlueScript SK + vector (Stratagene cloning system; Stratagene, La Jolla, Calif.). E. coli TG2 competent cells were then transformed with a portion of the reaction mixture. Recombinant colonies were selected by $\alpha$-complementation (32), and the size of the cloned plasmid was determined by agarose electrophoresis. After this, the plasmid was purified by using a Plasmid Midi kit (Qiagen, Hilden, Germany) The DNA sequence was determined on double-stranded DNA by the dideoxy chain termination method (30) and with the Applied Biosystems automatic DNA analysis system; this analysis was performed by workers at the Euro Sequence Gene Service, Montigny le Bretonneux, France. A total of 1,975 bp was sequenced. The sequence was then aligned with a representative collection of $16 \mathrm{~S}$ rRNA sequences. The alignment was performed with $1,450 \mathrm{bp}$. A multiple alignment, a phylogenetic tree, and levels of similarity were obtained by using MegAlign of the DNASTAR package (Promega, Madison, Wis.), the Clustal (version $\mathrm{V}$ ) method (9) with weighted residue, and the neighbor-joining method (29).

Quantitative DNA-DNA hybridization. The DNAs of the reference strains of Thermococcus celer, Thermococcus litoralis, and Thermococcus fumicolans were first used as labeled probes in a single hybridization experiment with strain $\mathrm{AL} 662^{\mathrm{T}}$, and strain AL662 ${ }^{\mathrm{T}}$ DNA was then used as the labeled probe in experiments with Thermococcus stetteri and Thermococcus profundus. Up to 20 liters of culture was needed to get enough DNA for the experiment. A 4- to 5- $\mu$ g portion of each reference strain DNA was labeled by incorporation of both $\left[{ }^{3} \mathrm{H}\right] \mathrm{dATP}$ and $\left[{ }^{3} \mathrm{H}\right] \mathrm{dGTP}$ by using a Megaprime kit (Amersham, Amersham Place, United Kingdom). The nuclease S1 method for quantitative DNA-DNA hybridization was carried out as described by Popoff and Coynault (25) by using DE81 filters (Whatman International, Maidstone, United Kingdom) and a $\beta$ matic IV scintillation counter (Kontron Instruments, Montigny le Bretonneux, France).

Nucleotide sequence accession number. The nucleotide sequence of the $16 \mathrm{~S}$ rRNA of strain AL $662^{\mathrm{T}}$ has been deposited in the GeneBank database under accession no. Z70244

\section{RESULTS}

Collection of samples. Chimney walls covered with Alvinnelids tubes were sampled by using the manned submersible "Alvin" during the American cruise MVT'90 in 1990 on the East Pacific Rise at a latitude of $21^{\circ} \mathrm{N}(26)$.

Enrichment and purification. After 2 or 3 days, increases in turbidity and microscopic observation indicated that growth had occurred. Purification was performed by plating samples onto solid sulfur-containing medium under anaerobic conditions (26).

Morphology. Phase-contrast microscopy revealed that isolate AL662 ${ }^{\mathrm{T}}$ cells were coccoid and occurred singly, in pairs, or in small aggregates (Fig. 1). The cell diameter ranged from 0.8 to $2 \mu \mathrm{m}$. The cells appeared to be motile, and polar flagella were observed by phase-contrast microscopy after specific coloration with Spot Test flagellum stain (Difco Laboratories, Detroit, Mich.). The cells most likely divided by constriction (data not shown). A two-layer cell envelope was observed with membrane fragments (Fig. 2).

Antibiotic susceptibility. Isolate $\mathrm{AL} 662^{\mathrm{T}}$ was resistant to vancomycin, penicillin, kanamycin, streptomycin, rifampin, and chloramphenicol, each at a concentration of $100 \mu \mathrm{g} / \mathrm{ml}$.

Lipid analysis. The polar lipid fraction of strain AL662 contained primarily glycerol ether lipids, and diphytanyl glycerol diether $\left(\mathrm{C}_{20}\right)$ was the predominant lipid and accounted for $80 \%$ of the total lipid fraction. In contrast, the tetraethers predominated (accounting for $75 \%$ of the total lipids) in the lipids extracted by the Bligh-Dyer method. No cyclopropane rings were observed either in the organic fraction or in the residual phase. The latter phase also contained a significant amount of unidentified compounds; complete identification of these unusual lipids is under way $(8 \mathrm{a})$.

Determination of growth parameters. Isolate AL662 ${ }^{\mathrm{T}}$ grew at 55 to $100^{\circ} \mathrm{C}$, and the optimum temperature for growth was 80 to $90^{\circ} \mathrm{C}$ (Fig. 3a). At the optimal temperature the generation time was around $90 \mathrm{~min}$; at $100^{\circ} \mathrm{C}$ it was around $5 \mathrm{~h}$. Growth was observed at $\mathrm{pH} 3.5$ to 9.5 , and the optimum $\mathrm{pH}$ was between 5.5 and 6.5 (Fig. 3b). Growth was observed at salt concentrations ranging from 20 to $80 \mathrm{~g} / \mathrm{liter}$, and the optimum salt concentration was between 30 and $40 \mathrm{~g} /$ liter (correspond- 

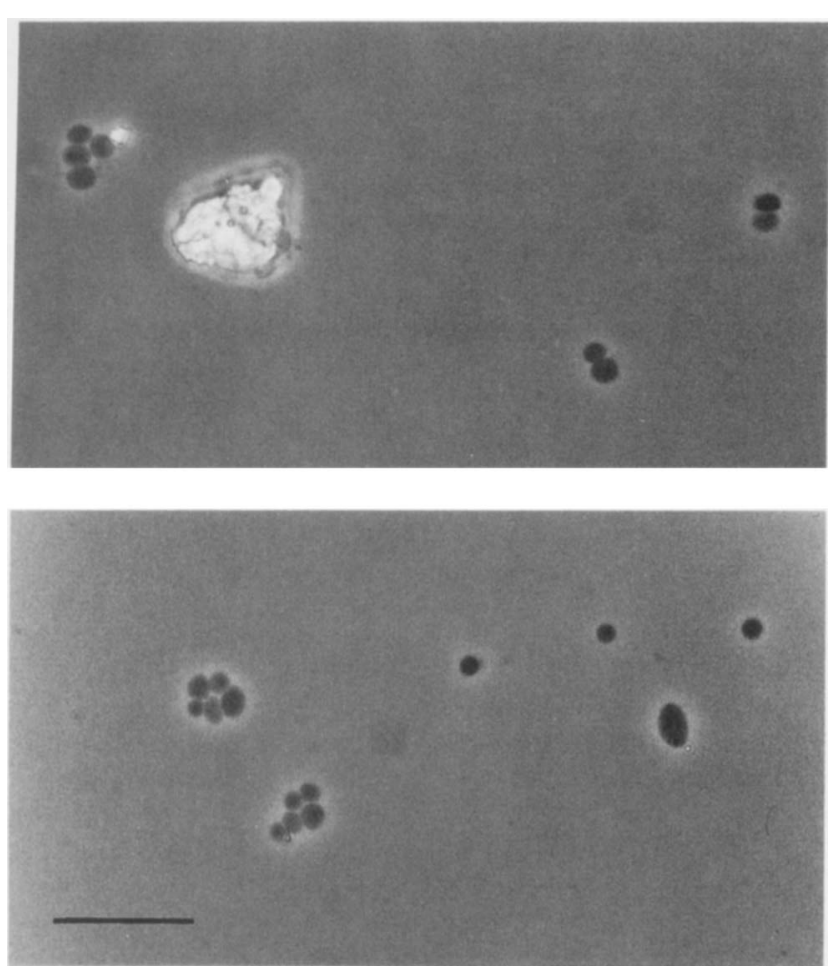

FIG. 1. Phase-contrast micrographs of strain $\mathrm{AL} 662^{\mathrm{T}}$. Bar $=10 \mu \mathrm{m}$.

ing to 19.5 to $26 \mathrm{~g}$ of $\mathrm{NaCl}$ per liter); no growth was detected at salt concentrations of 5, 10, and $100 \mathrm{~g}$ /liter (Fig. 3c).

Determination of growth requirements. $2216-\mathrm{S}$ media supported rapid growth of isolate AL662 ${ }^{\mathrm{T}}$. Yeast extract-peptone could be replaced by meat extract and brain heart infusion (Table 1). Significant growth was also observed on yeast extract, malt extract, peptone, and the 20 amino acids tested. Slow growth was also observed on casein and Casamino Acids. Maltose supported rapid growth of isolate AL662 ${ }^{\mathrm{T}}$. Growth on cellobiose and very low levels of growth on pyruvate were observed after $24 \mathrm{~h}$ of culture. None of the other sugars, alcohols, carboxylic acids, individual amino acids, or polysaccharides tested supported growth of isolate AL662 ${ }^{\mathrm{T}} . \mathrm{H}_{2}-\mathrm{CO}_{2}(80: 20)$ headspace gas did not support autotrophic growth and did not modify the growth of AL662 ${ }^{\mathrm{T}}$ on BHI-S medium (Table 1). Slow growth occurred in the absence of elemental sulfur, and growth was rapidly inhibited by $80 \% \mathrm{H}_{2}$ (Table 1). Cystine and polysulfide supported rapid growth of AL662 ${ }^{\mathrm{T}}$ (Table 1). When elemental sulfur was present in the culture medium, growth of AL662 ${ }^{\mathrm{T}}$ was accompanied by the production of large amounts of hydrogen sulfide (data not shown).

Organic acid production. In BHI-S and 20AA-S media, acetate (6.53 and $4.7 \mathrm{mM}$, respectively), phenyl acetate (3.06 and $0.83 \mathrm{mM}$ ), lactate $(1.17$ and $1.75 \mathrm{mM})$, and 2-methylpropionate (2.25 and $0.53 \mathrm{mM}$ ) were the major fermentation products; propanoate $(0.65$ and $0.79 \mathrm{mM})$, indoleacetate $(0.26$ and 0.37 $\mathrm{mM})$, 3-methylthiopropanoate $(0.87$ and $0.36 \mathrm{mM})$, and $p$ hydroxy-phenylacetate $(0.77$ and $0.2 \mathrm{mM})$ were also present.

DNA base composition. The $\mathrm{G}+\mathrm{C}$ content of the DNA of isolate $\mathrm{AL} 662^{\mathrm{T}}$ is $58 \mathrm{~mol} \%$.

16S rRNA sequence analysis. The sequence of the $16 \mathrm{~S}$ rRNA-encoding gene of strain AL662 ${ }^{\mathrm{T}}$ was determined and aligned with the other available $16 \mathrm{~S}$ rRNA sequences of strains belonging to the Thermococcales. A comparison of the $16 \mathrm{~S}$ rRNA sequences in which a phylogenetic tree was constructed
(Fig. 4) revealed that strain AL662 ${ }^{\mathrm{T}}$ belongs to the order Thermococcales. The levels of similarity between the $16 \mathrm{~S}$ rRNA of AL662 ${ }^{\mathrm{T}}$ and the $16 \mathrm{~S}$ rRNAs of other Thermococcus species are as follows: Thermococcus celer, 99.1\%; "Thermococcus litoralis," 94.5\%; Thermococcus profundus, 98.7\%; Thermococcus stetteri, 98.5\%; "Thermococcus peptonophilus," 97.2\%; and Thermococcus fumicolans, 93.9\%. The results of this analysis clearly indicate that $\mathrm{AL} 662^{\mathrm{T}}$ belongs to the genus Thermococcus.

DNA-DNA hybridizations. Considering the phylogenetic tree based on 16S rRNA gene sequences and considering the high levels of similarity (more than 98\%) (31) between the AL $662^{\mathrm{T}} 16 \mathrm{~S}$ rRNA gene sequence and the Thermococcus celer, Thermococcus profundus, and Thermococcus stetteri $16 \mathrm{~S}$ rRNA gene sequences, quantitative DNA-DNA hybridization experiments were performed. When strain AL662 ${ }^{\mathrm{T}}$ was used as the labeled probe, the levels of DNA reassociation were as follows: Thermococcus stetteri, 5\%; and Thermococcus profundus, $6 \%$. When reference strains were used as the labeled probes, the levels of DNA reassociation were as follows: Thermococcus celer, 26\%; "Thermococcus litoralis", 8\%; and Thermococcus fumicolans, 27\%. These data confirm that strain AL662 ${ }^{\mathrm{T}}$ is a new species of the genus Thermococcus.

\section{DISCUSSION}

The novel marine hyperthermophilic strain AL662 ${ }^{\mathrm{T}}$ belongs to the archaeal domain on the basis of its resistance to antibiotics, the presence of di- and tetraether lipids, and its $16 \mathrm{~S}$ rRNA sequence. The $\mathrm{G}+\mathrm{C}$ content and the $16 \mathrm{~S}$ rRNA sequence indicate that strain AL662 ${ }^{\mathrm{T}}$ belongs to the genus Thermococcus. The morphological and physiological characteristics of strain AL662 ${ }^{\mathrm{T}}$ are consistent with the morphological and physiological characteristics of this genus.

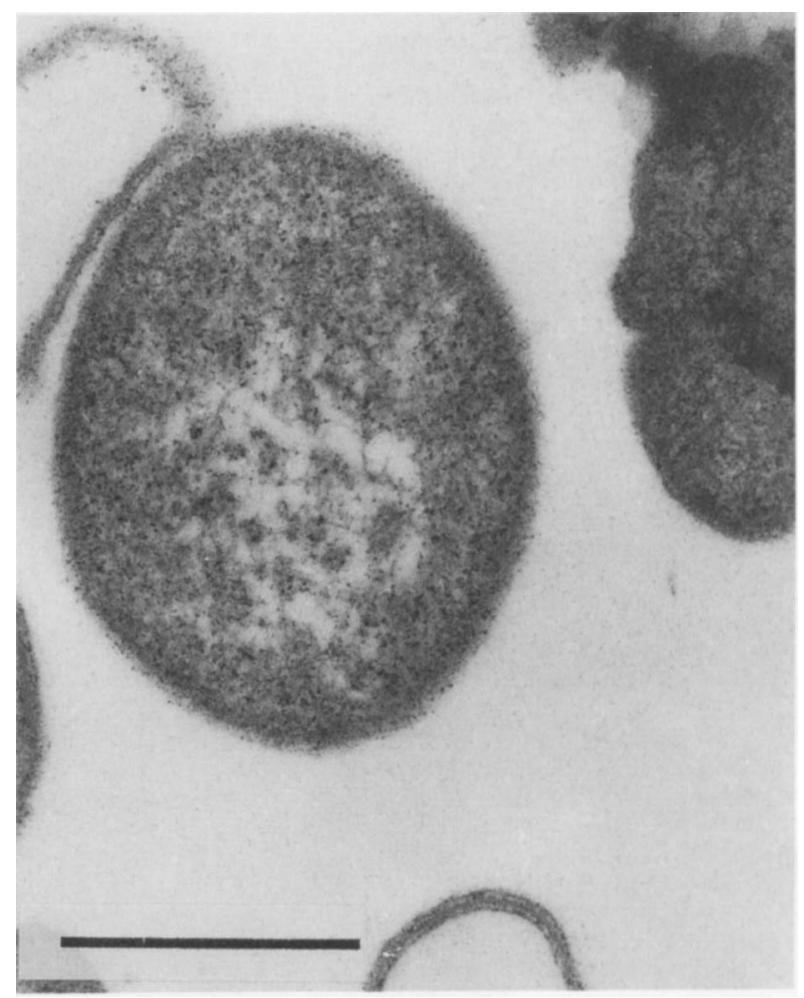

FIG. 2. Transmission electron micrograph of strain $\mathrm{AL} 662^{\mathrm{T}}$. Bar $=1 \mu \mathrm{m}$. 


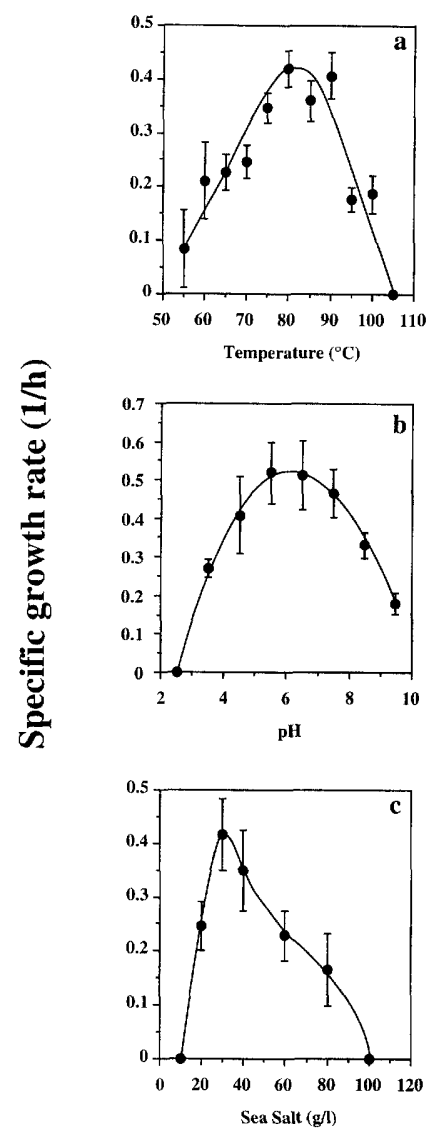

FIG. 3. Tempcrature, $\mathrm{pH}$, and Sea Salt concentration optima for growth of isolate AL $62^{\mathrm{T}}$ on 2216-S medium. (a) Specific growth rate as a function of temperature (in the presence of $30 \mathrm{~g}$ of Sea Salt per liter at $\mathrm{pH} 7.5$ ). (b) Specific growth ratc as a function of $\mathrm{pH}$ (in the presence of $30 \mathrm{~g}$ of Sea Salt per liter at $80^{\circ} \mathrm{C}$ ). (c) specific growth rate as a function of salinity (at $80^{\circ} \mathrm{C}$ and $\mathrm{pH} 7.5$ ). Growth rates were calculated by performing a linear regression analysis along the logarithmic parts of the growth curves. If enough data were available, information about the precision of the growth rate is given (regression coefficient \pm 2 standard errors).

Strain AL662 ${ }^{\mathrm{T}}$ differs from "Thermococcus litoralis," "Thermococcus alcaliphilus," and "Thermococcus chitonophagus" in its DNA G+C content; from Thermococcus stetteri, Thermococcus profundus, strain ES1 (24), and "Thermococcus alcaliphilus" in its temperature range (it grows at temperatures up to $100^{\circ} \mathrm{C}$ ); from "Thermococcus litoralis", Thermococcus profundus, "Thermococcus alcaliphilus", and Thermococcus fumicolans in its $\mathrm{pH}$ optimum; and from "Thermococcus litoralis", Thermococcus stetteri, Thermococcus profundus, "Thermococcus peptonophilus", and Thermococcus fumicolans in its resistance to rifampicin. Although the physiological features of strain AL662 $2^{\mathrm{T}}$ resemble those of Thermococcus celer, strain ${ }_{\mathrm{AL} 662^{\mathrm{T}}}$ is more tolerant to low salt concentrations. Thermococcus celer lyses at salt concentrations below $35 \mathrm{~g} /$ /iter (34). Strain AL662 ${ }^{\mathrm{T}}$ grows optimally in the presence of proteinaceous substrates and also on a mixture of 20 amino acids as sole carbon and energy sources, as previously described for other strains belonging to the order Thermococcales (7). Significant growth on maltose and slow growth on cellobiose, characteristics which have been observed previously for Thermococcus fumicolans, were observed, and a small amount of proteinaceous substrate is needed (7). Like the growth of most other Thermococcus species, the growth of strain AL662 ${ }^{\mathrm{T}}$ is not strictly dependent upon elemental sulfur. Elemental sulfur
TABLE 1. Growth requirements of strain AL662 ${ }^{\mathrm{T}}$

\begin{tabular}{|c|c|c|c|}
\hline \multirow{2}{*}{ Compound(s) } & \multicolumn{3}{|c|}{ Growth after ${ }^{a}$ : } \\
\hline & $8 \mathrm{~h}$ & $15 \mathrm{~h}$ & $24 \mathrm{~h}$ \\
\hline \multicolumn{4}{|l|}{ Carbon sources } \\
\hline Yeast extract-peptone (2216-S medium) & +++ & +++ & ND \\
\hline Meat extract & ++ & $++t$ & ND \\
\hline Yeast extract & + & ++ & +++ \\
\hline Malt extract & ++ & +++ & +++ \\
\hline Peptone & ++ & +++ & +++ \\
\hline Brain heart infusion (BHI-S medium) & +++ & $++t$ & ND \\
\hline Casein & + & ++ & ++ \\
\hline Casamino Acids & ND & - & + \\
\hline Glucose & - & - & - \\
\hline Sucrose & - & - & - \\
\hline Maltose & +++ & ND & +++ \\
\hline Cellobiose & + & ND & ++ \\
\hline Starch & - & - & - \\
\hline Ethanol & - & - & - \\
\hline Mannitol & - & - & - \\
\hline Acetate & - & - & - \\
\hline Pyruvate & - & + & + \\
\hline 20 Amino acids (20AA-S medium) & + & ++ & ++ \\
\hline None (under $\mathrm{H}_{2}-\mathrm{CO}_{2}$ ) & - & - & - \\
\hline BHI-S medium (under $\mathrm{H}_{2}-\mathrm{CO}_{2}$ ) & +++ & +++ & $\mathrm{ND}$ \\
\hline \multicolumn{4}{|l|}{ Electron acceptors } \\
\hline Sulfur & +++ & ND & +++ \\
\hline None (under $\mathrm{N}_{2}$ ) & ++ & ND & ++ \\
\hline None (under $\mathrm{N}_{2}-\mathrm{CO}_{2}, 80: 20$ ) & ++ & ND & ++ \\
\hline None (under $\mathrm{H}_{2}-\mathrm{CO}_{2}, 80: 20$ ) & - & ND & - \\
\hline Cystine & ++ & +++ & ND \\
\hline Polysulfide & ++ & ND & ND \\
\hline
\end{tabular}

$a+++,>2 \times 10^{8}$ cells per ml of culture (final concentration);,$++ 5 \times 10^{7}$ to $10^{8}$ cells per $\mathrm{ml}$ of culture (final concentration);,$+ 2 \times 10^{7}$ to $10^{7}$ cells per ml of culture (final concentration); - , no growth $\left(<10^{7}\right.$ cells per ml of culture); ND, not determined.

greatly enhances the growth of strain AL662 ${ }^{\mathrm{T}}$, but it can be replaced by cystine or polysulfide (however, growth is less efficient).

Strain AL662 ${ }^{\mathrm{T}}$ possesses an NADP-dependent ADH activity

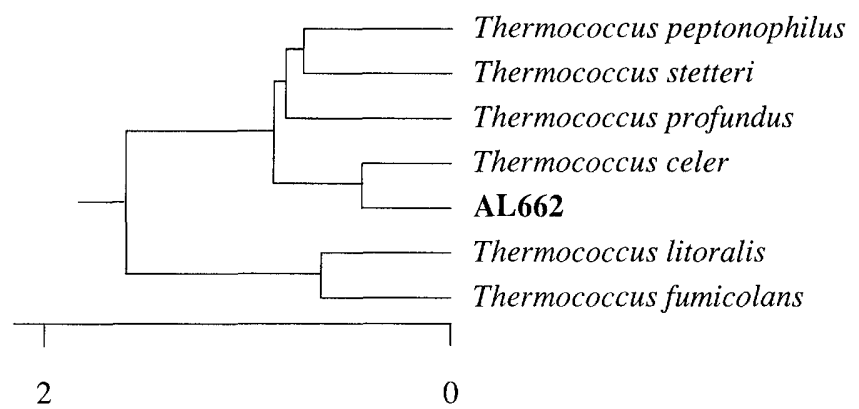

FIG. 4. Phylogenetic relationships based on $16 \mathrm{~S}$ rRNA sequences. Most of 16S rRNA sequences were obtained from the GenBank and EMBL databases. The exceptions were the sequences of Thermococcus litoralis, Thermococcus profundus, Thermococcus stetteri, and Thermococcus fumicolans, which were determined in our laboratory. Alignment was performed with sequences from representatives of Pyrococcus and Pyrodictium species. Only part of the resulting tree is presented. The units for the scale are number of substitution events inferred per $100 \mathrm{bp}$. The accession numbers of the sequences of the organisms used in this analysis are as follows: Thermococcus celer, M21529 I; "Thermococcus peptonophilus", D37982; Pyrococcus abyssi, L19921; Pyrococcus shinkai, D45214; Pyrococcus furiosus, U20163; Pyrodictium occultum, M21087; "Thermococcus litoralis", Z70251; Thermococcus profundus, Z75233; Thermococcus stetteri, Z75240; and Thermococcus fumicolans, Z70250. 
that oxidizes alcohol and reduces aldehydes (15). Purification and characterization of the enzyme are under way. Within the genus Thermococcus, "Thermococcus litoralis" and Thermococcus sp. strain ES1 have an NADP-specific ADH activity $(17,18)$, and it has been proposed that the physiological reaction of the enzyme might be aldehyde reduction. Ma and coworkers (17) have shown with Thermococcus sp. strain ES1 that the level of $\mathrm{ADH}$ activity increases when the amount of elemental sulfur is limited, and they have proposed that when sulfur is limiting, ADH reduces compounds to alcohols, the aldehydes that are generated during fermentation of amino acids, to remove excess reductant. Thus, the presence of ADH activity in strain AL662 ${ }^{\mathrm{T}}$, which is able to grow on amino acids, is not surprising.

On the basis of its morphological and physiological characteristics, its 16S rRNA sequences, and DNA-DNA hybridization data, new isolate AL662 ${ }^{\mathrm{T}}$ represents a new species of the genus Thermococcus. This species is named Thermococcus hydrothermalis because it was isolated from a hydrothermal area.

Description of Thermococcus hydrothermalis sp. nov. Thermococcus hydrothermalis (hy.dro.ther.mal'is. N.L. adj. hydrothermalis, pertaining to a hydrothermal vent). Cells are cocci (diameter, 0.8 to $2 \mu \mathrm{m}$ ) that are motile by means of polar flagella. Cell division occurs by constriction. Obligately anaerobic. Grows optimally in the presence of 30 to $40 \mathrm{~g}$ of Sea Salt per liter and at a pH around 6. Growth occurs at 55 to $100^{\circ} \mathrm{C}$, and the optimum temperature is around $85^{\circ} \mathrm{C}$. Obligately chemoorganotrophic. Grows preferentially on proteolysis products, a mixture of amino acids, and maltose. Sulfur is not necessary for growth but greatly enhances growth. The results of $16 \mathrm{~S}$ rRNA sequence comparisons place Thermococcus hydrothermalis in the Thermococcales. Type strain AL662 (= CNCMI1319 [Collection Nationale de Cultures de Microorganismes, Institut Pasteur, Paris, France]) was isolated from an active chimney wall fragment recovered from a hydrothermal site on the East Pacific Rise at a latitude of $21^{\circ} \mathrm{N}$.

\section{ACKNOWLEDGMENTS}

We thank the co-chief scientists of the cruise MVT'90, Richard A. Lutz and Robert Vriejenhoek (Institute of Marine and Coastal Sciences, Rutgers University, Rutgers, N.J.), and Daniel Desbruyères and Anne-Marie Alayse (IFREMER, Brest, France) for collecting samples. We thank Françoise Gaill and Lahcen Hamraoui for performing the transmission electron microscopy.

This work was supported by IFREMER, Région Bretagne, and the French Defense Ministry (DGA/DRET).

\section{REFERENCES}

1. Balch, W. E., G. E. Fox, L. J. Magrum, C. R. Woese, and R. S. Wolfe. 1979. Methanogens: reevaluation of a unique biological group. Microbiol. Rev. 43:260-296.

2. Belkin, S., and H. W. Jannasch. 1985. A new extremely thermophilic, sulfurreducing heterotrophic marine bacterium. Arch. Microbiol. 141:181-186.

3. Bligh, E. G., and W. J. Dyer. 1959. A rapid method of total lipid extraction and purification. Can. J. Biochem. Physiol. 37:911-917.

4. Blumentals, I. I., M. Itoh, G. J. Olson, and R. M. Kelly. 1990. Role of polysulfides in reduction of elemental sulfur by the hyperthermophilic archaebacterium Pyrococcus furiosus. Appl. Environ. Microbiol. 56:1255-1262.

5. Dauga, C., and P. A. D. Grimont. 1991. Nucleotide sequence of 16S rRNA from ten Serratia species. Res. Microbiol. 141:1139-1149.

6. Erauso, G., D. Prieur, A. Godfroy, and G. Raguénès. 1995. Plate cultivation techniques for strictly anaerobic, thermophilic, sulfur-metabolizing archaea, p. 25-29. In F. T. Robb and A. R. Place (ed.), Archaea: a laboratory manual. Thermophiles. Cold Spring Harbor Laboratory Press, Cold Spring Harbor, N.Y.

7. Godfroy, A., J.-R. Meunier, J. Guezennec, F. Lesongeur, G. Raguénès, A. Rimbault, and G. Barbier. 1996. Thermococcus fumicolans sp. nov., a new hyperthermophilic archaeum isolated from deep-sea hydrothermal vent in North Fiji basin. Int. J. Syst. Bacteriol. 46:1113-1119.

8. Gonzalez, J. M., C. Kato, and K. Horikoshi. 1995. Thermococcus peptonophilus sp. nov., a fast-growing, extremely thermophilic archaebacterium isolated from deep-sea hydrothermal vents. Arch. Microbiol. 164:159-164.
8a.Guezennec, J. Unpublished data.

9. Higgins, D. G., A. J. Bleasby, and R. Fuchs. 1992. CLUSTAL V: improved software for multiple sequence alignment. Comput. Applic. Biosci. 8:189191.

10. Hobbie, J. E., R. J. Daley, and S. Jasper. 1977. Use of Nuclepore filters for counting bacteria by fluorescence microscopy. Appl. Environ. Microbiol 33:1225-1228.

11. Huber, R., J. Stöhr, S. Honenhaus, R. Rachel, S. Burggraf, H. W. Jannasch, and K. O. Stetter. 1995. Thermococcus chitonophagus sp. nov., a novel, chitin-degrading, hyperthermophilic archaeum from a deep-sea hydrothermal environment. Arch. Microbiol. 164:255-264.

12. Kates, M. 1964. Bacterial lipids. Adv. Lipid Res. 2:17-90.

13. Keller, M., F.-J. Braun, R. Dirmeieir, D. Hafenbradl, S. Burggraf, R. Rachel, and K. O. Stetter. 1995. Thermococcus alcaliphilus sp. nov., a new hyperthermophilic archaeum growing on polysulfide at alkaline $\mathrm{pH}$. Arch. Microbiol. 164:390-395.

14. Kobayashi, T., Y. S. Kwak, T. Akiba, T. Kudo, and K. Horikoshi. 1994 Thermococcus profundus sp. nov. A new hyperthermophilic archaeon isolated from a deep-sea hydrothermal vent. Syst. Appl. Microbiol. 17:232-236.

15. Ladrat, C, L Cornec, A.M. Alayse-Danet, and G. Barbier, 1995. Mise en évidence d'enzymes thermostables chez des micro-organismes thermophiles d'origine hydrothermale. C. R. Acad. Sci. 318:423-429.

16. Langworthy, T. A., G. Holzer, J. G. Zeikus, and T. G. Tornabene. 1983. Isoand anteiso-branched glycerol diethers of the thermophilic anaerobe Thermodesulfotobacterium commune. Syst. Appl. Microbiol. 4:1-17.

17. Ma, K., H. Loessner, J. Heider, M. K. Johnson, and M. W. W. Adams. 1995 Effect of elemental sulfur on the metabolism of the deep-sea hyperthermophilic archaeon Thermococcus strain ES-1: characterization of a sulfur-regulated, non-heme iron alcohol dehydrogenase. J. Bacteriol. 177:4748-4756.

18. Ma, K., F. T. Robb, and M. W. W. Adams. 1994. Purification and characterization of NADP-specific alcohol dehydrogenase and glutamate dehydrogenase from the hyperthermophilic archaeon Thermococcus litoralis. Appl Environ. Microbiol. 60:562-568.

19. Marmur, J., and P. Doty. 1962. Determination of the base composition of deoxyribonucleic acid from its thermal denaturation temperature. J. Mol. Biol. 5:109-118.

20. Miroshnichenko, M. L., E. A. Bonch-Osmolovskaya, A. Neuner, N. A. Kos trikina, N. A. Chernych, and V. A. Alekseev. 1989. Thermococcus stetteri $\mathrm{sp}$ nov., a new extremely thermophilic marine sulfur-metabolizing archaebacterium. Syst. Appl. Microbiol. 12:257-262.

21. Moensch, T. T., and J. G. Zeikus. 1983. An improved preparation method for a titanium(III) media reductant. J. Microbiol. Methods 1:199-202.

22. Neuner, A., H. W. Jannasch, S. Belkin, and K. O. Stetter. 1990. Thermococ cus litoralis sp. nov.: a new species of extremely thermophilic marine archaebacterium. Arch. Microbiol. 153:205-207.

23. Pauly, G. G., and E. S. Van Vleet. 1986. Acyclic archaebacterial ether lipids in swamp sediments. Geochim. Cosmochim. Acta 50:1117-1125.

24. Pledger, R. J., and J. A. Baross. 1989. Characterization of an extremely thermophilic archaebacterium isolated from a black smoker polychaete (Paralvinella sp.) at the Juan de Fuca Ridge. Syst. Appl. Microbiol. 12:249 256.

25. Popoff, M. Y., and C. Coynault. 1980. Use of DEAE cellulose filters in the S1 nuclease method for bacterial deoxyribonucleic acid hybridization. Ann. Inst. Pasteur/Microbiol. (Paris) 131A:151-155.

26. Raguénès, G., J. R. Meunier, E. Antoine, A. Godfroy, J. C. Caprais, F. Lesongeur, J. Guezennec, and G. Barbier. 1995. Biodiversité d'Archaea hyperthermophiles de sites hydrothermaux du Pacifique oriental. C. R. Acad. Sci. 318:395-402.

27. Rimbault, A., J. Guezennec, M. Fromage, P. Niel, A. Godfroy, and F. Rocchiccioli. 1993. Organic acids and stable isotopes metabolic studies of a thermophilic sulfur-dependent anaerobic archaeon. J. Microbiol. Methods 18:329-338.

28. Saiki, R. K., D. H. Gelfand, S. Stoffel, S. J. Scharf, R. Higuchi, G. T. Horn, K. B. Mullis, and H. A. Erlich. 1988. Primer-directed enzymatic amplification of DNA with a thermostable DNA polymerase. Science 239:487-491.

29. Saitou, M., and M. Nei. 1987. The neighbor-joining method: a new method for reconstructing phylogenetic trees. Mol. Biol. Evol. 4:406-425.

30. Sanger, F., S. Nicklen, and A. R. Coulson. 1977. DNA sequencing with chain-terminating inhibitors. Proc. Natl. Acad. Sci. USA 74:5463-5467.

31. Stackebrandt, E., and B. M. Goebel. 1994. Taxonomic note: a place for DNA-DNA reassociation and 16S rRNA sequence analysis in the present species definition in bacteriology. Int. J. Syst. Bacteriol. 44:846-849.

32. Ullman, A., F. Jacob, and J. Monod. 1967. Characterization by in vitro complementation of a peptide corresponding to an operator-proximal segment of the $\beta$-galactosidase structural gene of Escherichia coli. J. Mol. Biol. 24:339.

33. White, D. C., J. D. Nickels, J. D. King, and R. J. Bobbie. 1979. Determination of the sedimentary microbial biomass by extractable lipid phosphate. Oecologia (Berlin) 40:51-62.

34. Zillig, W., I. Holtz, D. Janekovic, W. Schäfer, and W. D. Reiter. 1983. The archaebacterium Thermococcus celer represents a novel genus within the thermophilic branch of the archaebacteria. Syst. Appl. Microbiol. 4:88-94. 